\title{
Start-Up and Sustaining 20 Years of STEM Outreach Research and Programming: The Food, Mathematics, and Science Teaching Enhancement Resource (FoodMASTER) Initiative
}

\author{
Melani W. Duffrin'1, PhD, RDN; Virginia Stage², PhD, RDN; Ashley Roseno³, PhD, RDN; Jana Hovland4', PhD, RDN; \\ and Sebastian Diaz ${ }^{5}, \mathrm{PhD}$ \\ ${ }^{1}$ Division of Health Sciences, Northern Illinois University, Dekalb, Illinois; '2Department of Nutrition Science, East Carolina University, Greenville, North Carolina; \\ ${ }^{3}$ Department of Health Sciences, North Dakota State University, Fargo, North Dakota; ${ }^{4}$ Department of Food and Nutrition Science, Ohio University, Athens, Ohio; and \\ ${ }^{5}$ College of Medicine, Northeast Ohio Medical University, Rootstown, Ohio \\ Keywords: Education, Food, Nutrition, Science, Mathematics \\ Publication Date: August 10, 2020 \\ DOI: https://doi.org/10.15695/jstem/v3i2.05
}

\begin{abstract}
Science and mathematics literacy are fundamental to the basic understanding of food and health and/or the pursuit of science-based careers. In 1999, the FoodMASTER Initiative (FMI) was created to provide an opportunity for youth to experience authentic, real-world health science activities in K-12 learning environments. FMI administrative locations have included Ohio University 1999-2005, East Carolina University 2006-2018 and Northern Illinois University 2018-current. The key programmatic elements for the FMI include: 1) curricular hands-on activities developed with teacher input, 2) free online access, 3) rigorous evaluation of program materials, and 4) robust partnerships with organizations that promote mathematics and science education. The purpose of this manuscript will be to 1) provide a rationale for the FMI programming, 2) share the curriculum and the process for developing curriculum and summarize the quantitative and qualitative findings of the 19 peer-reviewed articles, 3) discuss funding that was secured, 4) discuss strategies that lead to program sustainability, 5) discuss the mission and vision, and 6) summarize programmatic component sustainability.
\end{abstract}

\section{INTRODUCTION}

The Committee on STEM Education of the National Science and Technology Council (NSTC) clearly articulates a need for Americans to have access to lifelong science, mathematics, technology, and engineering (STEM) learning opportunities. Unfortunately, learners often become frustrated with science knowledge acquisition because information is taught without context, making it difficult to grasp the importance of the concept (Pajares, 1992). Guiding the development of STEM learning activities with Next Generation Science Standards (NGSS) and selecting subject matter content on learner's preexisting knowledge (Saunders, 1992) in combination with strategic pathways representing cross-cutting approaches (NSTC, 2018) can serve to empower all learners towards effective, productive citizenship.
While subject matter selection, meeting content standards, and creating relevance are important factors, teaching methods and approach should also be carefully considered if educators are to impact a learner's attitude and confidence towards science learning (Pajares et al., 2014). To date, traditional lecture-style and read-write learning style approaches continue to be the default teaching style for many educators. It is easy, efficient, and works for many learners; however, it often fails to appeal to a wide variety of learning styles, inspire curiosity, and create a love of learning. Educators must be willing and prepared to provide more engaging experiences for students that involve inquiry, hands-on learning, group discussion, questioning, demonstrations, problems, drawing, projects, and other teaching methods if they are 
going to achieve quality outcomes (Kelly, 2000).

In 1999, a partnership was created between a rural elementary school teacher and a practicing rural dietitian and university faculty in Southeast Ohio to use food as a tool to teach food, science, and mathematics. Knowing that science and mathematics literacy are fundamental to individuals' basic understanding of food and health and/or the pursuit of science-based careers, the two professionals created a STEM program called the FoodMASTER Initiative. The purpose of the FoodMASTER Initiative (FMI) was to create a science education program rooted in constructivist learning theory (Phillips et al., 2004). Food was selected as the teaching tool because 1) students have preexisting experiences with foods, 2) it is conducive to hands-on activities, and 3) concepts can be linked to course content in biology, chemistry, environmental sciences, mathematics, nutrition, and health. Additional consideration for the use of food included: 1) food is already relevant for the learner, 2) food is an easily accessible material, 3) positive science and mathematics learning experiences can be inspired with various foods, and 4) food experiences can span across the P-20 learning environment in both formal and informal learning environments.

Given that the foundation of food and nutrition is rooted in mathematics and science subject matter, along with the potential to engage and inspire an individual's desire for lifelong science learning, the FMI team was compelled to examine food and nutrition education through various teaching and learning methods (Stage et al., 2015). The multidisciplinary team of science, nutrition, and health educators began to discuss how to create a program for mathematics and science teachers that would allow for more time in the classroom devoted to issues related to food and nutrition while maintaining the required learning objectives of the Mathematics Standards Common Core State Initiative and Next Generation Science Standards (NGSS). Instead of using a traditional health education approach, the team focused on foundational mathematics and scientific knowledge to apply basic good nutritional science principles in the classroom. The advantages of this approach would be to 1) expand the number of teachers in the school system discussing food and health sciences, 2) support the acquisition of foundation knowledge that would further enhance knowledge in science and mathematics, and 3) increase the number of content hours in nutrition science without taking time away from the core subject matter that is required, taught, and assessed with standardized testing.

\section{PROGRAM MISSION AND VISION}

The core mission of the FMI was established to address a long-standing lack of realistic sciences education opportunities for youth. The program vision is to provide teachers with authentic learning activities for classroom implementation to improve access, knowledge, and attitudes of youth towards science education (Diaz et al., 2018; Duffrin et al., 2010; Hovland et al., 2013; Roseno et al., 2014; Stage et al., 2017).

\section{FUNDING SECURED}

FoodMASTER began as a self-funded project partnering Ohio University with rural elementary students to learn mathematics and science using food. The project was called Kitchen Wizards and quickly demonstrated robust learning outcomes for both elementary and university students (Duffrin et al., 2005; McLeod et al., 2012). The project also captured the attention of Ohio University 1804 funds committee which provided additional funding to expand the proof-ofconcept to six classrooms in Southeast Ohio.

In 2003, the Kitchen Wizard concept was modified and renamed the FoodMASTER Initiative. In 2005, team FMI received a National Institutes of Health (NIH) Science Education Partnership Award (SEPA). In 2008, the FMI received project funding from the United States Department of Agriculture. NIH SEPA remains the primary funder of the FMI.

\section{KEY PROGRAMMATIC ELEMENTS}

The FMI encourages teacher adoption of the FMI approach by alleviating what teachers and administrators might perceive as barriers to implementation. The developers created the curricular materials to 1) address science learning standards, 2) provide proficiency type questions, 3) use affordable food, supplies, and equipment, and 4) ensure

Table 1. Funding Sources.

\begin{tabular}{lll}
\hline Years & FoodMASTER Projects & Funding Source \\
\hline $1999-2003$ & Concept development & \\
$2003-2004$ & Elementary Grades & Ohio University 1804 funds \\
$2005-2008$ & Grade 3-5 Phase I & NIH Science Education Partnership Award R25RR020447 \\
$2008-2010$ & Grade 3-5 Phase II & NIH Science Education Partnership Award R25RR020447-04 \\
$2008-2010$ & FM Higher Education & USDA Higher Education Challenge Award NCE- 2008-38411-19041 \\
$2011-2016$ & Grade 6-8 & NIH Science Education Partnership Award R25RR032144-01 \\
$2017-2022$ & Informal Science Learning & NIH Science Education Partnership Award R25GM129216 \\
\hline
\end{tabular}


Table 2. FoodMASTER Workbook General Topic Content.

\begin{tabular}{|c|c|c|c|c|c|}
\hline Topic & $\begin{array}{c}\text { Grade 3-5 } \\
\text { Science }\end{array}$ & $\begin{array}{c}\text { Grade 3-5 } \\
\text { Math }\end{array}$ & $\begin{array}{c}\text { Grade 6-8 } \\
\text { Science }\end{array}$ & $\begin{array}{c}\text { Grade 6-8 } \\
\text { Math }\end{array}$ & Higher Ed \\
\hline Weights \& Measures & Chapter 1 & Chapter 1 & Chapter 1 & & Chapter 2 \\
\hline Food Safety & Chapter 2 & Chapter 2 & Chapter 2 & & Chapter 1 \\
\hline Vegetables & Chapter 3 & Chapter 3 & Chapter 3 & & Chapter 3 \\
\hline Fruit & Chapter 4 & Chapter 4 & Chapter 4 & & Chapter 4 \\
\hline Milk and Cheese & Chapter 5 & Chapter 5 & Chapter 5 & & Chapter 7 \\
\hline Meat, Fish, Poultry & Chapter 6 & Chapter 6 & Chapter 6 & & Chapter 9 \\
\hline Eggs & Chapter 7 & Chapter 7 & Chapter 6 & & Chapter 8 \\
\hline Fats and Oil & Chapter 8 & Chapter 8 & Chapter 9 & & Chapter 10 \\
\hline Grains & Chapter 9 & Chapter 9 & Chapter 7 & & Chapter 5 \\
\hline Meal Management & Chapter 10 & Chapter 10 & & & \\
\hline Energy Balance & & & Chapter 10 & Activities 1-4 & \\
\hline Food Composition & & & & Activities 5-8 & \\
\hline Super Tasters & & & & Appendix & \\
\hline Sugar & & & Chapter 8 & & Chapter 6 \\
\hline Quick Breads & & & & & Chapter 11 \\
\hline Yeast Breads & & & & & Chapter 12 \\
\hline
\end{tabular}

that all materials are teacher tested and revised with relevant feedback. The curriculum includes the features of reinforcing healthy food selection, encouraging reading comprehension, and providing take-home activities for children and families to implement in the home learning environment.

Curriculum Development. FoodMASTER grades 3-5 was the first curricular manual developed, with twenty-four activities within 10 topic areas (see Table 2). Workbook activities introduce subject matter and promote reading comprehension through clever "Doodle bugs." "Doodle bugs" encourages reading comprehension of the pertinent content for each chapter by asking students to underline or circle key concepts. Next, students and teachers must read and implement a hands-on activity. These activities generally use food as a hands-on tool to convey a scientific and/or mathematics concept.

Workbook developers created activities that require basic household cooking equipment, can be conducted in a regular classroom environment, and use food ingredients that are easily accessible. Other considerations are to provide as many edible end products as possible, especially using healthy food choices. While science and mathematics are the primary learning objectives, food and/or nutrition concepts are also integrated into each activity.

The workbook encourages students to demonstrate learning through laboratory reports and discussion; however, proficiency questions are available at the end of each chapter. These questions can assist the learner in checking basic knowledge and provide an opportunity for responding to standardized questioning. The workbooks provide addition- al lessons to give students the opportunity to demonstrate thinking and learning skills in a "Try this at home" learning environment. The FoodMASTER grades 3-5 mathematics supplement, FoodMASTER grades 6-8 Science, FoodMASTER grades 6-8 Mathematics, and FoodMASTER Higher Education follow similar strategies, adjusted for grade level.

While FoodMASTER resource materials apply some variation in learning objectives and approaches, the process generally includes the following: 1) initial development of the curricular material based on educators' needs and input, 2) pilot testing and implementation with formative evaluations 3) advisory panel review and revisions, 4) final implementation, and 5) data analysis after final revisions.

Workbooks for each learning level are guided by food subject matter and integration of science and mathematics concepts. All workbook activities are guided by and aligned with the Next Generation Science Standards (NGSS) and Common Core Mathematics Standards. NGSS and Common Core activity alignments can be found in the corresponding educator resources. Educators can choose to use the entire workbook or select individual activities based on their students' learning needs and interest. Educator manuals, website videos, and teacher professional development activities assist educators in identifying the meaningful science and mathematics concepts within each chapter.

FoodMASTER workbook materials are evaluated by educators throughout the process of development. Curriculum developers utilize appropriate grade level teachers as consultants during the first stages of development. Workbook materials are then tested in a classroom or multiple classrooms and implementation teachers provide extensive feed- 

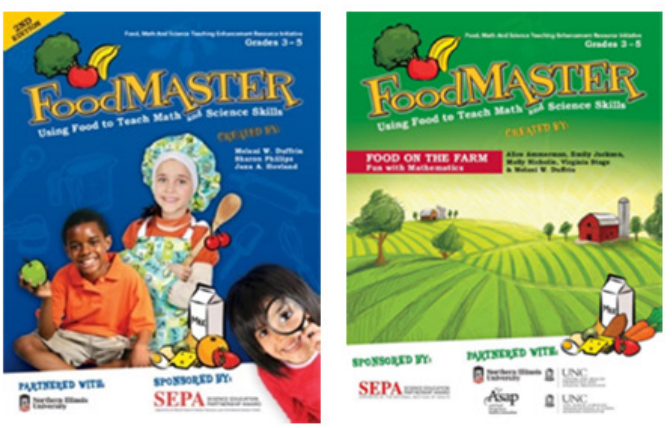

Grades 3-5 Science and Mathematics
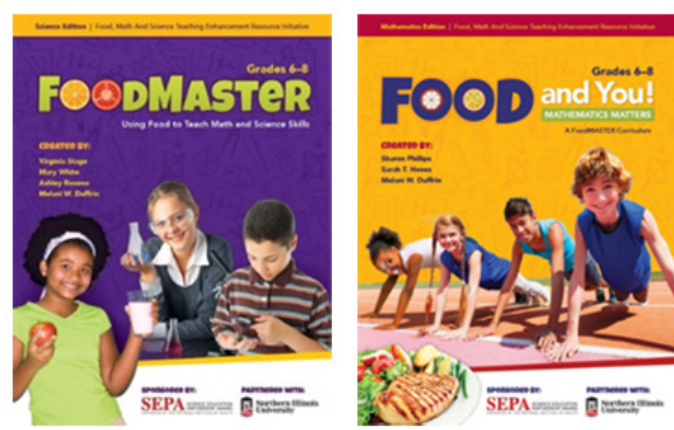

Grades 6-8 Science and Mathematics

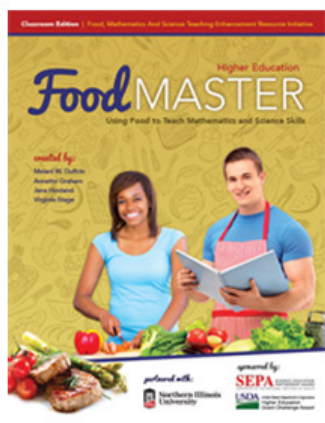

Higher Education

Figure 1. FoodMASTER Workbooks. Graphic Art by Cara Cairns Design

back to revise materials in working towards a final product.

Curriculum Design. Workbook graphic design takes place prior to final implementation. The FoodMASTER activity material are produced by a professional graphic designer. This artistic enhancement improves visual appeal of the written information and applies high quality pictures and graphics. Educators who participate in final implementation receive printed hard copies and provide additional feedback post implementation. After the final implementation feedback is assessed, minor revisions are made to the final product. Finalized materials are then posted online, maintained free of charge, and made publicly available at www.foodmaster.org.

Curriculum and Material Access. FMI team members decided that all curricular materials would be available to educators free of charge. At the completion of each 5-year project, efforts have been made to ensure that curriculum and other research products are shared publicly. This effort effectively removes the barrier of cost for educators wanting to access materials.

Any potential user can go to the FMI website - www. foodmaster.org and download materials for free. Currently, the website contains grades 3-5, 6-8, and higher education resource manuals (see Figure 1). The FMI also partnered with another free website at the USDA National Agricultural in the Classroom, to offer components of both the FMI grades 3-5 and 6-8 materials.

The FMI team also prints and distributes free resource materials to educators through project participation and professional development opportunities. FMI book printing cost ranges from $\$ 12$ to $\$ 50$, depending on the size of the manual or workbook.

Evaluation of Materials and Programs. Recognizing the importance of data to support the development and utilization of FMI workbook materials, educational research and evaluation is a component of all projects. The grades 3-5 and
6-8 science workbook projects have applied the most funding thus far to provide extensive research and evaluation. Both projects were implemented and evaluated in multiple classrooms with participating educators in Ohio and North Carolina classrooms.

FMI institutional locations have determined where classrooms would be located for implementation and evaluation. Schools in desired geographic locations were approached directly with information about projects; teacher participation has been voluntary. School administration support was obtained before contacting teachers; this support was essential for subsequent voluntary teacher participation. In cases where well-matched comparison classrooms were utilized, teacher participation was also voluntary.

All research projects were approved by university Institutional Review Boards and participant consents were obtained. When students were involved, parental consent was also obtained. Students in implementation classrooms were not required to participate in research to be part of program implementation. In the cases of well-matched comparison classrooms, teachers in those classrooms received all the same program support materials as the implementation teachers after data collection period.

Grades 3-5 Food on the Farm, Grades 6-8 Food and You, and FoodMASTER Higher Education, have not undergone as extensive evaluation as have the Grades 3-5 and 6-8 science workbook activities. However, data from the grades 3-5 and 6-8 science workbook research informed much of the

Table 3. Project Descriptions.

\begin{tabular}{|c|c|c|c|}
\hline Years & Projects & Geographic Location & $\begin{array}{l}\text { Intervention } \\
\text { Classrooms }\end{array}$ \\
\hline $2003-2004$ & $\begin{array}{l}\text { Elementary } \\
\text { Grades }\end{array}$ & Southeast Ohio & 1 \\
\hline $2005-2008$ & $\begin{array}{l}\text { Grade 3-5 } \\
\text { Phase I }\end{array}$ & Southeast Ohio & 10 \\
\hline $2008-2010$ & $\begin{array}{l}\text { Grade 3-5 } \\
\text { Phase II }\end{array}$ & Ohio and North Carolina & 18 \\
\hline 2011-2016 & Grade 6-8 & Eastern North Carolina & 9 \\
\hline
\end{tabular}


Table 4. Pilot Study Research Descriptions.

\begin{tabular}{|c|c|c|c|c|c|c|}
\hline Author(s)/Year & Title & Description & Methods & Population & $\mathbf{N}$ & Journal \\
\hline $\begin{array}{l}\text { Phillips, S.K. et al., } \\
\text { (2004) }\end{array}$ & Be a Food Scientist & $\begin{array}{l}\text { Implementation and evalu- } \\
\text { ation of a 14-week program } \\
\text { called Kitchen Wizards }\end{array}$ & $\begin{array}{l}\text { Implementation } \\
\text { and Observation }\end{array}$ & $\begin{array}{l}\text { 4th grade student } \\
\text { in South East (SE) } \\
\text { Ohio }\end{array}$ & 40 & Science and Children \\
\hline $\begin{array}{l}\text { Duffrin, M. et al., } \\
(2005)\end{array}$ & $\begin{array}{l}\text { Developing Food } \\
\text { Products and } \\
\text { Enthusiastic Learners }\end{array}$ & $\begin{array}{l}\text { Field trip experience for col- } \\
\text { lege and elementary school } \\
\text { students designed around a } \\
\text { food product development } \\
\text { assignment }\end{array}$ & $\begin{array}{l}\text { Implementation } \\
\text { and Observation }\end{array}$ & $\begin{array}{l}\text { College and } \\
\text { elementary grade } \\
\text { students in SE } \\
\text { Ohio }\end{array}$ & 56 & $\begin{array}{l}\text { Journal of Family and } \\
\text { Consumer Sciences }\end{array}$ \\
\hline $\begin{array}{l}\text { Rivera, D. et al., } \\
(2009)\end{array}$ & $\begin{array}{l}\text { Improving Elemen- } \\
\text { tary School Students' } \\
\text { Learning Outcomes } \\
\text { Using Food-based } \\
\text { Mentorship Programs }\end{array}$ & $\begin{array}{l}\text { Food-based mentorship pro- } \\
\text { gram involving college and } \\
\text { elementary school students }\end{array}$ & $\begin{array}{l}\text { Implementation, } \\
\text { surveys, open-end } \\
\text { comments, and } \\
\text { observation }\end{array}$ & $\begin{array}{l}\text { College and } \\
\text { elementary grade } \\
\text { students in SE } \\
\text { Ohio }\end{array}$ & 36 & $\begin{array}{l}\text { Journal of Teaching in } \\
\text { Travel \& Tourism }\end{array}$ \\
\hline
\end{tabular}

development of these materials. Efforts to implement and evaluate these products are on-going.

In general, FMI research projects collect both formative and summative data to evaluate outcomes and program effectiveness. Evaluation methods include process evaluation of educator efficacy (Roseno et al., 2017; Stage et al., 2016), student knowledge (Hodges et al., 2017; Hovland et al., 2013; Roseno et al., 2014; Stage et al., 2015) student attitudes, and dietary intake assessment. Data collection techniques include observations, pre and post knowledge assessment and surveys, and educator interviews. Table 4 summarizes data collected during pilot studies and table 5 and 6 summarize the grades 3-5 and 6-8 science workbook research. Evidence supporting the use of FMI approach and materials is drawn from these studies.

Pilot Studies. Pilot studies (Table 4) demonstrated successful student engagement and learning. The elementary students displayed enthusiasm for the curricular content and were engaged when utilizing food as a tool to learn science. Involving college students in the program enhanced their learning as well, especially through a mentorship process. Pilot study results warranted further exploration of the use of food as tools to engage elementary grade students in learning science. Subsequent to the first pilot studies, Kitchen Wizards was renamed FoodMASTER and further changes were made to the program content.

Grades 3-5 Studies. Of the eight studies completed with grades 3-5 (Table 5), two focused on attitudes, one focused on implementation of a mathematics lesson, four focused on knowledge gains, and one focused on nutrition teaching efficacy. Six of the eight studies utilized a pre and posting testing data set from a year-long implementation of the finalized grades 3-5 workbook. Educators utilizing the entire grades 3-5 workbook expose students to an average of 18 hours of food-based education over the academic year.

In general, students in all grades 3-5 activities were ob- served as engaged participants. Overall, student participants' attitudes towards science increased at the completion of activities. The knowledge domains of nutrition, science, and mathematics (tested with researcher developed exams) indicated a collective increase in scores for all domains and a significant difference in scores between the intervention and well-matched comparison groups. Educator participants displayed gains in self-efficacy toward teaching nutrition that were significantly greater than changes observed in the educator well-matched comparison group.

Grades 3-5 project dissemination generated interest in expanding project concepts at higher grade levels. FoodMASTER expanded its resources to include middle grades 6-8 with the creation of a new science workbook. This workbook followed a similar subject matter, development, and research approach as the grades 3-5 workbook.

Grades 6-8 Studies. Of the two completed studies with grades 6-8 (Table 6), one focused on nutrition knowledge exam development and one focused on process evaluation. The studies evaluated educators and students in sixteen classrooms in Eastern North Carolina over the course of a year-long implementation of the grades 6-8 workbook lessons.

The nutrition knowledge exam included appropriate levels of item difficulty. Further analysis of student participant nutrition knowledge and attitudes remains in progress. For process evaluation, educators felt the program was a valuable experience for middle school students and were willing to repeat over half the chapters. Educators reported that the motivating factors for repeating activities included student enjoyment, standard alignment, ease of instructions, professional development training experience, and the provision of additional resources.

Overall, the pilot test, grades $3-5$, and grades $6-8$ projects have produced quality products and data to support the continued use and expansion of the FoodMASTER initiative. Additional data and details can be found in the 19 peer-re- 
Table 5. Grade 3-5 Research Descriptions.

\begin{tabular}{|c|c|c|c|c|c|c|}
\hline Author(s)/Year & Title & Description & Methods & Population & $N$ & Journal \\
\hline $\begin{array}{l}\text { Duffrin, M. et al. } \\
\text { (2010) }\end{array}$ & $\begin{array}{l}\text { Using Food as a Tool } \\
\text { to Teach Science to 3rd } \\
\text { Grade Students in Appa- } \\
\text { lachian Ohio }\end{array}$ & $\begin{array}{l}\text { Attitudes towards science } \\
\text { survey pre and post imple- } \\
\text { mentation of } 45 \text { hands on } \\
\text { food lessons }\end{array}$ & $\begin{array}{l}\text { Survey pre and } \\
\text { post-test }\end{array}$ & $\begin{array}{l}\text { Fourth graders in } \\
\text { Southeast Ohio }\end{array}$ & 280 & $\begin{array}{l}\text { Journal of Food } \\
\text { Science Education }\end{array}$ \\
\hline $\begin{array}{l}\text { McLeod, S. et al. } \\
(2012)\end{array}$ & $\begin{array}{l}\text { Measuring Me: Using } \\
\text { Nutrition Education } \\
\text { Curriculum Activities to } \\
\text { Teach Elementary Math- } \\
\text { ematics }\end{array}$ & $\begin{array}{l}\text { Implementation of math- } \\
\text { ematics activity in fourth } \\
\text { grade classrooms }\end{array}$ & $\begin{array}{l}\text { Implementation } \\
\text { and Observation }\end{array}$ & $\begin{array}{l}\text { Fourth graders in } \\
\text { North Carolina }\end{array}$ & 298 & $\begin{array}{l}\text { Journal of } \\
\text { Nutrition } \\
\text { Education and } \\
\text { Behavior }\end{array}$ \\
\hline $\begin{array}{l}\text { Hovland, J. et al. } \\
\text { (2012) }\end{array}$ & $\begin{array}{l}\text { Food-Based Science } \\
\text { Curriculum Increases 4th } \\
\text { Graders Multidisciplinary } \\
\text { Science Knowledge }\end{array}$ & $\begin{array}{l}\text { Fourth graders science } \\
\text { knowledge gains }\end{array}$ & $\begin{array}{l}\text { Science } \\
\text { knowledge pre } \\
\text { and post-test } \\
\text { Well-matched } \\
\text { comparison }\end{array}$ & $\begin{array}{l}\text { Fourth graders in } \\
\text { Ohio and North } \\
\text { Carolina }\end{array}$ & 580 & $\begin{array}{l}\text { Journal of Food } \\
\text { Science Education }\end{array}$ \\
\hline $\begin{array}{l}\text { Roseno, A. et al. } \\
(2013)\end{array}$ & $\begin{array}{l}\text { Applying Mathematical } \\
\text { Concepts with Hands- } \\
\text { on, Food-Based Science } \\
\text { Curriculum }\end{array}$ & $\begin{array}{l}\text { Fourth graders mathematics } \\
\text { knowledge gains }\end{array}$ & $\begin{array}{l}\text { Mathematics } \\
\text { knowledge pre } \\
\text { and post-test } \\
\text { Well-matched } \\
\text { comparison }\end{array}$ & $\begin{array}{l}\text { Fourth graders in } \\
\text { Ohio and North } \\
\text { Carolina }\end{array}$ & 482 & $\begin{array}{l}\text { School Science \& } \\
\text { Mathematics }\end{array}$ \\
\hline $\begin{array}{l}\text { Stage, V. et al. } \\
(2015)\end{array}$ & $\begin{array}{l}\text { Food-based Science Cur- } \\
\text { riculum Yields Gains in } \\
\text { Nutrition Knowledge }\end{array}$ & $\begin{array}{l}\text { Fourth graders nutrition } \\
\text { knowledge gains }\end{array}$ & $\begin{array}{l}\text { Nutrition } \\
\text { knowledge pre } \\
\text { and post-test } \\
\text { Well-matched } \\
\text { comparison }\end{array}$ & $\begin{array}{l}\text { Fourth graders in } \\
\text { Ohio and North } \\
\text { Carolina }\end{array}$ & 473 & $\begin{array}{l}\text { Journal of School } \\
\text { Health }\end{array}$ \\
\hline $\begin{array}{l}\text { Stage, V. et al. } \\
(2016)\end{array}$ & $\begin{array}{l}\text { Implementation of a } \\
\text { Food-based Science } \\
\text { Curriculum Improves 4th } \\
\text { Grade Educator's Self-ef- } \\
\text { ficacy for } \\
\text { Teaching Nutrition }\end{array}$ & $\begin{array}{l}\text { Fourth grade educator's } \\
\text { self-efficacy for teaching } \\
\text { nutrition }\end{array}$ & $\begin{array}{l}\text { Self-efficacy pre } \\
\text { and post-test } \\
\text { Well-matched } \\
\text { comparison }\end{array}$ & $\begin{array}{l}\text { Fourth grade } \\
\text { educators }\end{array}$ & 34 & $\begin{array}{l}\text { American Journal } \\
\text { of Health } \\
\text { Education }\end{array}$ \\
\hline $\begin{array}{l}\text { Stage, V. et al. } \\
\text { (2017) }\end{array}$ & $\begin{array}{l}\text { Exploring Associations } \\
\text { among Nutrition Sci- } \\
\text { ence, and Mathematics } \\
\text { Domains of Knowl- } \\
\text { edge for an Integrative } \\
\text { Food-based Curriculum: } \\
\text { A Multiple Regression } \\
\text { Analysis }\end{array}$ & $\begin{array}{l}\text { Multiple regression exploring } \\
\text { associations among nutrition, } \\
\text { science, and mathematics } \\
\text { knowledge }\end{array}$ & $\begin{array}{l}\text { Secondary data } \\
\text { analysis of grade } \\
3-5 \text { nutrition, } \\
\text { science, and } \\
\text { mathematics } \\
\text { knowledge } \\
\text { testing data }\end{array}$ & $\begin{array}{l}\text { Fourth graders in } \\
\text { Ohio and North } \\
\text { Carolina }\end{array}$ & 438 & $\begin{array}{l}\text { Journal of School } \\
\text { Health }\end{array}$ \\
\hline $\begin{array}{l}\text { Diaz, S. et al. } \\
(2018)\end{array}$ & $\begin{array}{l}\text { The Importance of Im- } \\
\text { proving Youths' } \\
\text { Attitudes Toward } \\
\text { Science (ATS): Vali- } \\
\text { dation of a Short Form } \\
\text { Assessment of Attitudes } \\
\text { in Science Constructs for } \\
\text { Fourth Grade (AASC-4) }\end{array}$ & $\begin{array}{l}\text { Validation of attitude towards } \\
\text { science survey utilizing grade } \\
3-5 \text { survey data }\end{array}$ & $\begin{array}{l}\text { Secondary anal- } \\
\text { ysis of grade } 3-5 \\
\text { attitudes towards } \\
\text { science survey } \\
\text { data }\end{array}$ & $\begin{array}{l}\text { Fourth graders in } \\
\text { Ohio and North } \\
\text { Carolina }\end{array}$ & 1117 & $\begin{array}{l}\text { Journal of STEM } \\
\text { Outreach }\end{array}$ \\
\hline
\end{tabular}

viewed publications that are listed in the reference section of this manuscript. The reference section includes publications on preschool (Geist et al., 2011; Roseno et al., 2015) and higher education (Duffrin, 2003, Rivera et al., 2009; Willard and Duffrin, 2003) projects that were outside the focused scope of the grades 3-5 and 6-8 projects.
Outreach and Partnerships. Robust partnerships are a key component of FMI research and development projects. Teacher partnerships had been the primary focus for FMI in earlier projects, and community educator partnerships have been the focus of later projects. Both formal science learning environment partnerships with K-12 teachers and informal science learning environments with community educators are the key to programming success. 
Table 6. Grade 6-8 Research Descriptions.

\begin{tabular}{|c|c|c|c|c|c|c|}
\hline Author(s)/Year & Title & Description & Methods & Population & $\mathrm{N}$ & Journal \\
\hline $\begin{array}{l}\text { Hodges, C. et al. } \\
(2017)\end{array}$ & $\begin{array}{l}\text { Middle school } \\
\text { nutrition knowledge } \\
\text { tool development in } \\
\text { North Carolina. }\end{array}$ & $\begin{array}{l}\text { Knowledge assessment of the } \\
\text { FoodMASTER middle grades } \\
6-8 \text { workbook in } 10 \text { classrooms } \\
\text { in Eastern North Carolina. }\end{array}$ & $\begin{array}{l}\text { Nutrition } \\
\text { knowledge pre } \\
\text { and post-test }\end{array}$ & $\begin{array}{l}\text { Seventh grade stu- } \\
\text { dents in Eastern } \\
\text { North Carolina }\end{array}$ & 250 & $\begin{array}{l}\text { Nutrition and Food } \\
\text { Science }\end{array}$ \\
\hline $\begin{array}{l}\text { Roseno, A. et al. } \\
(2017)\end{array}$ & $\begin{array}{l}\text { Process Evaluation of } \\
\text { an Integrative, Food- } \\
\text { based Science Cur- } \\
\text { riculum in 8th Grade } \\
\text { North Carolina Science } \\
\text { Classrooms. }\end{array}$ & $\begin{array}{l}\text { Process evaluation of im- } \\
\text { plementation of the Food- } \\
\text { MASTER middle grades } 6-8 \\
\text { workbook in } 10 \text { classrooms in } \\
\text { Eastern North Carolina. }\end{array}$ & $\begin{array}{l}\text { Implementation, } \\
\text { observation, } \\
\text { feedback, exit } \\
\text { survey, and exit } \\
\text { interviews }\end{array}$ & $\begin{array}{l}\text { Seventh grade } \\
\text { teachers in Eastern } \\
\text { North Carolina }\end{array}$ & 8 & $\begin{array}{l}\text { Health Behavior } \\
\text { and Policy Review }\end{array}$ \\
\hline
\end{tabular}

Formal Science Learning Environments. Initially, partnerships with K-12 teachers and schools were the foundation for the FMI. A strong partnership with teachers was necessary to enhance the quality of the materials and to move program expansion forward. It was the proof of concept data and endorsement of previous FMI teacher(s) that provided FMI researchers the ability to establish new teacher partnerships. When approaching new teacher partnerships, it was important to create interest and establish trust.

The process of establishing partnerships required several one-on-one teacher meetings. To begin teacher partnerships, first teacher contacts aim to establish interest in the FMI and to provide information about participation in current projects. For teachers expressing interest, FMI researcher(s) visit the teacher at their school and spend two hours with the teacher explaining project participation in further detail.

Once a teacher partnership is established, FMI researchers work with the teacher to gain school administrative approvals and set up project participation expectations. Over the course of a project, teachers receive multiple site visits from the project coordinator to support implementation and partnership building. At the conclusion of the grades 3-5 and 6-8 projects, the FMI had partnered with a total of 31 Ohio and 46 North Carolina classroom teachers.

Informal Science Learning Environments. As a component of the grades 6-8 project, the FMI proposed the development of a summer science experience for middle grade youth. This summer science experience forged a new partnership opportunity. Networking within the science education community introduced the FMI team to community organizations expressing interest in utilizing FMI workbook activities for science education programming.

As a result of the summer science camp experience, a robust partnership formed with a local North Carolina - organization called the Love A Sea Turtle Foundation (LAST). LAST promotes environmental advocacy through youth community service and science education. A large component of LAST programming involves food and nutrition, as well as protecting food systems. LAST supports youth lead- ership development and provides services to underrepresented youth.

The FMI and LAST partnership have served to reach thousands of youth in Eastern North Carolina with access to FMI programming, leadership opportunities, and an experience in informal science education. Initial summer day camp programming in partnership with the Love A Sea Turtle Foundation in Eastern North Carolina included 258 Boys and Girls Club members. LAST has continued to assist the FMI by reaching youth through additional partnership with organizations that provide opportunities for underserved youth such as the Boys and Girls Clubs, Police Athletic League, and the SPOT.

Professional Development. As another component of outreach and partnerships, the FMI provides teacher and other professional development opportunities. The FMI team members have provided teacher professional development workshops to 270 elementary and middle school teachers through partnerships with the National Science Teachers Association regional meetings, Annual Environmental Health Sciences Summer Institute for K-12 Texas Educators, North Carolina Association for Biomedical Research, and the Northern Illinois University P-20 Center. The FMI team has also partnered with the School Nutrition Services Dietetics Practice Group of the Academy of Nutrition and Dietetics, introducing the FMI concept in a workshop to 58 registered dietitians attending the 2011 Food and Nutrition Conference Expo.

\section{SUSTAINABILTY}

The FMI team works diligently to address its biggest challenge, sustainability. One component is current project partnerships with six universities and one nonprofit 501(c) (3) organization. The goal is developing and delivering FMI concepts in science education programming. While still a work in progress, the university partnerships aim to support mentorship-based project partnerships. These mentorships can continue to expand and establish successful programs in other communities. 
At the 20-year anniversary of the initiative, the team created a significant amount of curricular materials and data to support the use of FMI materials. The FMI team has found that partnering and mentorship with formal and informal science education organizations appears to be the keys to expansion and sustainability success. Current efforts are underway to permanently integrate and establish the FMI within the structure of the Northern Illinois University P-20 Center. The FMI team believes new opportunities are rooted in educator professional development, along with continued strategic mentor-based program expansion.

\section{ASSOCIATED CONTENT}

More detailed acknowledgements and free materials can be found at www.foodmaster.org.

\section{AUTHOR INFORMATION Corresponding Author}

Melani W. Duffrin, PhD, RDN, Professor. School of Interdisciplinary Health Professions, Northern Illinois University. Wirtz Hall 323. Dekalb, IL 60115. (815) 753-5118. mduffrin@niu.edu

\section{Author Contributions}

The manuscript was written through contributions of all authors. All authors have given approval to the final version of the manuscript.

\section{ACKNOWLEDGMENTS}

FMI team members thank Sharon Phillips, the first partner teacher, and all the partner educators for connecting students with the FMI. Dr. Christopher Duffrin and Paula Wilson provided behind the scene ideas and editing support. Program and grants management staff from the National Institute of General Medical Sciences (NIGMS) at the NIH provided valuable support and guidance. The team thanks co-authors, program partners and researchers, administrators, students, advisory panels, and program officers who have supported the program and its mission.

\section{FUNDING SOURCES}

The funds from the NIH Science Education Partnership Award (R25RR020447, R25RR020447-04, R25RR032144-01, R25GM129216) and USDA Higher Education Challenge Award (NCE- 2008-38411-19041) have provided necessary support.

\section{ABBREVIATIONS}

FMI: FoodMASTER Initiative; HEC: Higher Education Challenge; LAST: Love A Sea Turtle Foundation; NGSS: Next Generation Science Standards; NIGMS: National Institute of General Medical Sciences; NIH: National Institutes of Health; ; P-20: Preschool through Higher Education; SEPA: Science Education Partnership Award; STEM: Science, Mathematics, Technology, and Engineering; USDA: United States Department of Agriculture

\section{REFERENCES}

Committee on STEM Education of the National Science and Technology Council (2018). Charting a course for success: America's Strategy for STEM Education. Report. Retrieved from: https://www.whitehouse.gov/wp-content/uploads/2018/12/STEM-Education-Strategic-Plan-2018.pdf

Diaz, S., Roseno, A., Stage, V., Moore, S., Lynch, A., Dickerson, D., and Duffrin, M. (2018). The Importance of improving youths' attitudes toward science (ATS): Validation of a short form assessment of attitudes in science constructs for fourth grade (AASC-4). Journal of STEM Outreach.

Duffrin, M. (2003). Integrating problem-based learning in an introductory college food science course. Journal of Food Science Education, 2(1), 2-6.

Duffrin, M., Cuson, D., Phillips, S.K., and Graham, A.S. (2005). Developing Food Products and Enthusiastic Learners. Journal of Nutrition Education and Behavior, 37(1):41-42.

Duffrin, M., Cuson, D., and Phillips, S.K. (2005). Using foods to boost math and science skills. Journal of Family and Consumer Sciences, 97(1), 64-65.

Duffrin, M., Hovland, J., Carraway-Stage, V., McLeod, S., Duffrin, C., Phillips, S., Rivera, D., Saum, D., Johanson, G., Graham, A., Lee, T., Bosse, M., and Berryman, D. (2010). Using food as a tool to teach science to 3rd grade students in appalachian Ohio. Journal of Food Science Education, 9(2), 41-46.

Geist, E.A., Duffrin, M., and Overholt, S.A. (2011). Eating up mathematics! Teaching Children Mathematics, 17(9), 568.

Hodges, C., Roseno, A, Duffrin, M.W., and Stage, V. (2017). Middle school nutrition knowledge tool development in North Carolina. Nutrition and Food Science, 47(3), 332-345.

Hovland, J., Carraway-Stage, V., Cela, A., Collins, C., Diaz, S., Collins, A., and Duffrin, M. (2013). Food-based science curriculum increases 4 th graders multidisciplinary science knowledge. Journal of Food Science Education, 12(4), 8186.

Hovland, J., McLeod, S., Duffrin, M., Johanson, G., and Berryman, D. (2010). School-based dietary intake screening of 3rd graders in rural Appalachia Ohio. Journal of School Health, 80(11), 536-543. 
Kelly, J. (2000). Rethinking the elementary science methods course: A case for content, pedagogy, and informal science education. International Journal of Science Education, 22(7), 755-777.

McLeod, S., Carraway-Stage, V., Hovland, J., and Duffrin, M. (2012). Measuring me: Using nutrition education curriculum activities to teach elementary mathematics. Journal of Nutrition Education and Behavior, 44(2), 189-191.

NGSS Lead States. (2013). Next Generation Science Standards: For States, By States. Retrieved from https://www.nextgenscience.org/

Pajares, M. F. (1992). Teachers' beliefs and educational research: Cleaning up a messy construct. Review of Educational Research, 62(3), 307-332.

Phillips, S.K., Duffrin, M., and Geist, E.A. (2004). Be a food scientist. Science and Children, 41(4), 24-29.

Povtin, P., and Hasni, A. (2014). Interest, motivation, and attitude toward science and technology at K-12 levels: A systematic review of 12 years of educational research. Studies in Science Education, 50, 1, 85-129.

Rivera, D., Duffrin, M., and Phillips, S. (2009). Improving elementary school students' learning outcomes using foodbased mentorship programs. Journal of Teaching in Travel and Tourism, 9(3-4), 144-158.

Roseno, A., Carraway-Stage, V., Hoerdemann, C., Diaz, S., Geist E., and Duffrin, M. (2014). Applying mathematical concepts with hands-on, food-based science curriculum. School Science and Mathematics, 115(1), 14-21.

Roseno, A., Carraway-Stage, V., Geist, G., and Duffrin, M. (2015). Exploring sunflower seeds: A thematic approach to science inquiry for young children. Young Children, 70(3), 88-91.

Roseno, A., Duffrin, M.W., and Stage, V. (2017). Process evaluation of an integrative, food-based science curriculum in 8 th grade North Carolina science classrooms. Health Behavior and Policy Review, 4(5), 491-502.

Saunders, W. L. (1992). The constructivist perspective: Implications and teaching strategies for science. School Science and Mathematics, 92(3), 136.

Stage, V., Diaz, S., Hovland, J.A., Kolasa, K., and Duffrin, M.W. (2017). Exploring associations among nutrition science, and mathematics domains of knowledge for an integrative food-based curriculum: A multiple regression analysis. Journal of School Health, 88(1), 15-2.

Stage, V., Hovland, J., Ochab, C., Diaz, S., and Duffrin, M. (2015). Food-based science curriculum yields gains in nutrition knowledge. Journal of School Health, 85(4), 231-240.

Stage, V., Roseno, A., Hodges, C., Hovland, J., Diaz, S., and Duffrin, M.W. (2016). Implementation of a food-based science curriculum improves 4th grade educator's self-efficacy for teaching nutrition. American Journal of Health Education, 47 (3), 155-162.
Willard, K., and Duffrin, M. (2003). Utilizing project-based learning and competition to develop student skills and interest in producing quality food items. Journal of Food Science Education, 2(4), 69-73. 